Check for updates

The BMJ

Cite this as: BMJ 2021;373:n1327 http://dx.doi.org/10.1136/bmi.n1327 Published: 25 May 2021

\title{
Covid-19: Public debate is needed to decide how UK will live with SARS-CoV-2, says ethics collaborative
}

\section{Elisabeth Mahase}

As the UK eases its covid-19 restrictions, and the initial two-dose vaccination rollout nears its end, more radical forms of public engagement will be essential when resolving the difficult questions about how the country will live with SARS-CoV-2, the UK Pandemic Ethics Accelerator collaborative has said.

As part of the collaborative, researchers from the universities of Oxford, Bristol, Edinburgh, and University College London considered some of the challenging ethical questions that the pandemic has raised.

The accelerator has been funded by $£ 1.4 \mathrm{~m}$ from the Arts and Humanities Research Council, as part of the rapid response to covid of UK Research and Innovation, the non-departmental government body that directs research and innovation funding. The pandemic has resulted in 130 ooo covid-19 deaths in the UK and three million worldwide. Many people have also been affected by long covid.

The researchers initially focused on the key ethical challenges relating to large scale data collection, access, and use; preparedness for future pandemics; access to resources such as vaccines; and the use of public health interventions such as quarantine. They also considered how to create equitable public health policy and practice and to ensure engagement of the public in informing policy making.

In five articles, published $24 \mathrm{May},{ }^{1}$ the researchers concluded:

- The current suppression strategy means society "will have to make trade-offs between three key values: reducing covid-19 mortality, liberty, and equality" and will have to decide what is acceptable for the fundamental conflict between these values to be resolved.

- Rather than just focusing on communicating risk to the public in terms of numbers and epidemiological data, policy makers need a better understanding of how the public judges and responds to risk and what values influence these judgments.

- New ways of gathering data on covid-19 deaths and which groups are being affected by inequality are needed. For example, anthropologists have developed approaches that don't just count people but also provide insight into their lives and values.

- When the government makes decisions on everything from education and employment to trade and travel it should consider ethical questions concerning effects on health (harms and benefits), and the public should be involved in that discussion.
The accelerator's principal investigator, Ilina Singh, co-director of the Wellcome Centre for Ethics and Humanities at the University of Oxford, said, "As a society we all will still need to make trade-offs to suppress the virus in the long term. Those decisions will affect us all. For example, the measures to reduce deaths and protect health services have created risks and impacts elsewhere, including increased waiting list times and people becoming reluctant to seek medical help, as well as impacts on mental health, child development, and education.

"In terms of mortality, the pandemic is now forcing us to consider what sorts of deaths, and whose deaths, we should be most concerned about, as well as the values that underpin such judgments. Untimely or unexpected deaths are something to be avoided-but at what cost?”

1 UK Pandemic Ethics Accelerator. Living and dying with covid-19-an ethical perspective is vital [press release]. 24 May 2021. https://ukpandemicethics.org/living-and-dying-with-covid-19-an-ethical-perspective-isvital-press-release.

This article is made freely available for use in accordance with BMJ's website terms and conditions for the duration of the covid-19 pandemic or until otherwise determined by BMJ. You may use, download and print the article for any lawful, non-commercial purpose (including text and data mining) provided that all copyright notices and trade marks are retained. 